\title{
MEMBANGKITKAN SEMANGAT UMAT ISLAM
}

\author{
Hartono* \\ hartono4alazhar@gmail.com \\ *Dosen Magister Pendidikan Islam, Universitas Muhammadiyah Tangerang
}

\begin{abstract}
The resurrection people of prophet Muhammad Saw is a God mercy to all nature. Therefore, the treatiseis considered as a resurrection to humanity. With the treatise of humanity, people rose from ignoranceto a civilized life.
\end{abstract}

Keyword :Resurrection, Ignorance, Civilized

\section{A. PENDAHULUAN}

"Masa depan akan menjadi milik Islam dan hanya untuk Islam serta kekuasaan akan menjadi milik hakikat Al Qur'an dan keimanan. Karena itu menjalani kehidupan dengan ridha dan pasrah pada Allah, sebab kita memiliki masa depan yang cerah". Hal itu disebutkan menurut Badi'uzzaman Said Nursi dalam Khutbah Syamiyah manifesto kebangkitan umatIslam.

Said Nursi dan Badi'uzaman (2014:18), berbagai esensi Islam dikenal memiliki potensi dan kesiapan untuk mendorong pemeluknya menggapai dua hal yaitu satu; kemajuan maknawi (spiritual) dan kedua ; fisik (material) Satu; Potensi menggapai kemajuan maknawi (spiritual ).

Lanjut Said Nursi dan Badi'uzaman, sejarah mencatat berbagai kejadian nyata menjadi bukti atas hakikat sejumlah peristiwa. Sejarah memperlihatkan, panglima Jepang telah mengalahkan Rusia memberi kesaksian terkait dengan kebenaran Islam yang mengatakan bahwa Kekuatan hakikat Islam dan komitmen kaum muslim terhadap hakikat tersebut membuat mereka semakin maju dan meningkat. Sebaliknya, ketika mereka kurang berpegang kepada hakikat kebenaran, mereka tertinggal, jatuh ke dalam carut marut yang mengakibatkan lemah takberdaya.

Adapun seluruh agama selain Islam yang terjadi justru sebaliknya, artinya lemahnya komitmen terhadap agama membuat mereka semakin maju sebaliknya berpegang pada agama mereka semakin terpuruk dan terjatuh.

Seandainya dengan prilaku, kita memperlihatkan akhlak Islam dan kesempurnaan hakikat Islam, dapat dipastikan pengikut agama lain masuk ke dalam Islam secara berbondongbondong, bahkan bisa terjadi negaranegara di dunia berikut benuanya memeluk Islam.

Umat manusia bangkit dan sadar dengan berbagai pengetahuan modern mulai memahami hakikat dan esensi agama diperlukan dalam kehidupan. Apalagi ketika menghadapi permasalahan tentunya kembali pada agama. Selanjutnya sebagian besar ayat AlQur'an mengarahkan manusia pada akal dengan maksud firman Allah kembalilah pada akal dan fikiran wahai manusia agar hakikat kebenaran tampak jelas.

Dari uraian tersebut dapat disampaikan bahwa kaum muslimin merupakan pelayan Al Qur'an, mengikuti 
petunjuk, menerima hakikat keimanan dengan akal, fikiran dan hati. Karena itu, masa depan yang berada dalam genggaman akal dan pengetahuan akan dipimpin oleh kekuasaan Al-Qur'an yang hukum-hukumnya bersandar pada akal, Logika dan bukti nyata.

Sala satu contoh kemajuan dan kebangkitan Islam seperti menurut $\mathrm{Mr}$. Carlyle ( salah satu tokoh abad 19 dan filsuf terkenal di benua Amerika ) yang menarik perhatian para filsuf dan ilmuwan Nasrani dengan perkataannya :

"Islam datang kepada berbagai ajaran palsu dan kepercayaan yang bathil lalu menelannya. Hal tersebut tepat dan layak . Pasalnya ialah hakikat yang keluar dari jantung alam. Begitu Islam datang, seluruh berhala arab dan dialektika nasrani hangus terbakar. Semua yang tidak benar menjadi kayu, hangus dimakan api hingga lenyap, namun apinya tidak lenyap".

Dua ; Potensi untuk menggapai kemajuan Aspek Material

Al-Qur'an sebagai guru yang mendorong manusia untuk mencapainya. Seolah-olah ia berkata : "Ayo bekerja dan berusahalah untuk mengaplikasikannya sebagai mukjizat. Tempuhlah, misalnya jarak dua bulan menjadi satu hari sebagaimana yang dilakukan nabi Sulaiman AS. Berusalah mengobati penyakit yang paling berat sebagaimana yang dilakukan nabi Isa As“".

Dua hal tersebut menjadi contoh upaya fisik yang dilakukan untuk memperoleh hasil yang diaplikasikan dalam kehidupan. Tentunya memerlukan perjuangan dan pengorbanan untuk mencapai hasil maksimal. Seperti inspirasi tersebut yang memberikan tuntutan agar umat Islam secara maksimal menggunakan potensi untuk dapat menciptakan kecepatan yang 'sangat super' dalam waktu sekejap dapat memindahkan atau bepergian ke suatu tempat ditempuh tidak memerlukan waktu yang berlama-lama.

Contoh lain banyak berbagai macam penyakit yang muncul sesuai dengan penyakit jaman milenial seperti virus Corona atau penyakit lain yang belum ditemukan obatnya. Kondisi ini memotivasi akan keyakinan umat Islam bahwa segala sesuatu pasti ada obatnya.

\section{A. PEMBAHASAN}

Kehadiran nabi Muhammad Saw pada abad ke 6 adalah merupakan rahmat bagi seluruh alam . Oleh karenanya kedatangan risalah dianggap sebagai kebangkitan / bi'tsah bagi umat manusia.Dengan risalah umat manusia bangkit dari kejahiliannya menuju kehidupan yang berperadaban di bawah pimpinan rasulullah Muhammad Saw.

Kebangkitan ini kemudian mengantarkan umat Islam pada kebangkitannya yang pertama saat umat Islam meraih prestasi yang amat gemilang dengan prestasinya di jaman keemasan ( Golden Age ) ketika Islam hadir untuk mengubaha arah sejarah dunia dari yang sebelumnya mandek dan penuh kebiadaban menuju keadaan yang maju dan berperadaban.

Para khalifah rasulullah yang arif (al-Khulafa al-rasyidin) dan para pelanjutnya, para khalifah yang memimpin kekhalifahannya Islam dengan prestasinya membangun peradaban yang memberi manfaat besar bagi perkembangan sejarah dunia dan umat manusia serta membawa pada keadaan yang jauh lebih maju dan tertib. 
Kebangkitan pertama ini dapat diketahui dalam dua periode. Pertama, masa Rasulullah dan khulafa al-Rasyidin (571-661 M). Periode kedua, adalah sejak masa Umayah (661-750 M) hingga runtuhnya Baghdad (Abad ke-13) sebagai ibukota kekhalifahan Islam yang memberi kontribusi yang tak terhingga bagi peradaban umat manusia.

Kebangkitan tersebut pada dasarnya merupakan pembangunan tatanan masyarakat yang lebih bertuhan (Rabbaniyah) dan berkeadaban. Seperti diketahui, Rasulullah Saw memutarjarum jam sejarah dari kehidupan yang pagan dan barbar menjadi kehidupan yang Rabbaniyah dan berkeadaban. Setelah berada di Madinah, Rasulullah bersama khalifah membangun masyarakat yang beradab dan sangat modern untuk ukuran saat itu yang tatanan sosialnya diletakkan di atas altar Piagam Madinah (Misaq alMadinah) (Al-Imam Abi Muhammad 'abdul Malik bin Hisyam, 2006).

Kebangkitan Islam saat itu digerakkan oleh semangat meneliti dan mengembangkan ilmu yang tinggi di kalangan umat sehingga melahirkan sains yang kemudian berhasil memposisikan umat Islam menjadi mediator kebangkitan peradaban kuno dan era sesudahnya (M.M. Syarif, 2001).

Kebangkitan kedua, terjadi setelah Napoleon Bonaparte melakukan ekspansi ke Mesir (1798) yang kemudian membuka jalan baru bagi umat Islam untuk bangkit. Ekspedisi ini telah menyulut semangat umat Islam (spirit of Islam) untuk bangkit. Kebangkitan kedua ini penekanannya adalah upaya bangkit melawan dan melepaskan diri dari kolonialisme Barat serta kehendak secara sadar untuk mengambil alih peradaban modern yang tersembul di Barat yang sesungguhnya merupakan milik seluruh umat manusia, termasuk umat Islam, seperti yang didendangkan oleh Muhammad Ali, Jamaluddin al-Afghani, Muhammad Abduh,dan murid- muridnya di Mesir. Sayyid Ahmad Khan, Iqbal dan Ali Jinnah di India. Sultan Mahmud, Badi'uzzaman Said Nursi di Turki. Khomeini, Ali Syari'ati dan lain-lain di Iran. Agus Salim, Sukarno, Hatta, Harun Nasution, Habibie, Nurchalish Madjid dan lain-lain di Indonesia. Demikian juga di wilayah-wilayah lainnya yang secara serempak bangkit dari tidurnya yang lelap di bawah imperialisme dan berupaya memajukan umat Islam dengan mengambil alih peradaban modern.

Sejak akhir abad ke-20 dan awal abad ke-21 (abad ke-15 Hijriyah), umat Islam telah menemukan kesadaran baru bahwa mereka harus bangkit dan memiliki kemajuan dalam berbagai bidang kehidupan.Kebangkitan ini dapat disebut sebagai kebangkitan ketiga saat umat Islam menyadari betapa mereka harus bangkit untuk turut mengambil bagian dalam transformasi dunia menuju globalisasi.

Sehubungan dengan kesadaran tentang perlunya kebangkitan itu pengalihan peradaban modern hendaknya sebagai usaha sungguh-sungguh kebangkitan bukan sekedar pengambilan peradaban dari Barat. Hal tersebut perlu dikedepankan mengingat banyaknya tokoh dan pemikir yang memajukan kritikan keras terhadapnya apakah Islam saat ini berada dalam keadaan maju ? Atau umat Islam sedang berada di pojok sejarah. Pertanyaan ini meskipun dikedepankan oleh para pemikir semisal Murad Willfred Hoffman, namun ia tampak arus umum 
dari kegerahan seluruh pemerhati masa depan Islam (Futurulog Muslim) sehingga pembicaraan mengenai kebangkitan Islam merupakan bagian integral dari perkembangan modern dalam Islam.

Di antara persepsi yang muncul mengenai kondisi umat Islam (secara global) pada saat ini yaitu pertama,sebagian umat Islam melihat bahwa mereka dalam degradasi yang terus menerus ke bawah, semenjak kedatangan Islam di Madinah. Alasan yang mendasari pemahaman ini antara lain sabda rasulullah Saw :

"Dari 'Umrah bin Husain dari nabi Saw: Sebaik-baik umatku adalah abad saat aku diutus, kemudian abad berikutnya dan kemudian datang kaum yang bersaksi namun tidak dipercaya janjinya (HR. Bukhari , Muslim, Abu Dawud dan Tirmidzi).

Kedua, sebagian umat Islam berkeyakinan bahwa sejarah umat Islam berjalan dalam bentuk gelombang yang terdiri atas gerakan naik turun, seperti spiral.

Ketiga, sebagian umat Islam berkeyakinan bahwa umat Islam berada dalam kemajuan yang terus menerus sepanjang jaman.

Ketiga pendapat ini dapat dikategorikan kepada pihak yang optimis dan pihak yang pesimis dengan alasan dan dalil masing-masing. Yang optimis menguatkan pendapatnya dengan ayat-ayat al Qur'an dan Hadits yang menggambarkan bahwa Islam akan Berjaya dan jika mereka mengusahakannya. Di antaranya QS. 3 / Ali Imran : 110 ; QS. 13 / ar Ra'du : 11 ; QS.110/an-Nasr : 2.

Alasan yang berdasarkan hadits Rasulullah Saw yang berbunyi :
"Sesungguhnya Allah akan mengutus bagi umat ini pada setiap awal seratus tahun orang yang akan memperbaharui agamanya" ( HR.Abu Dawud).

Untuk pihak pesimis mengajukan alasan antara lain hadits yang diriwayatkan oleh Jabir bin Abdullah dan Abi Hurairah : “ Manusia masuk ke dalam agama Allah dengan berbondong- bondong dan akan keluar dengan berbondong-bondong". (HR.al-Hakim dan menshahihkannya).

Kebangkitan Islam sangat penting untuk dikaji dan dimotivasi agar tidak pernah redup dan dapat memimpin proses perkembangan dunia yang semakin mengglobal . Hal tersebut karena umat Islam yang memiliki jumlah yang kian hari semakin meningkat bahkan telah menjadi gejala di dunia terutama setelah terjadinya peristiwa pengeboman WTC di Amerika Serikat tahun 2001 yang diklaim / dimanipulasi dilakukan oleh orang Islam.

Melihat perkembangan jumlah umat Islam yang berkembang dari waktu ke waktu, Murad Wilfred Hoffmann menuliskan :

"Saat ini tidak seorangpun yang berani memprediksikan bahwa Islam akan lenyap. Bahkan sebaliknya bahwa Islam akan terus berkembang . Para Jenderal NATO memperkirakan bahwa gelombang militer yang akan terjadi pada masa mendatang bukan antara Timur dan Barat akan tetapi Utara dan Selatan”.

Murad mengetengahkan bahwa pada pertengahan abad 21 telah bermunculan gerakan kebangkitan Islam, muncul dari bawah dan dari atas . Masjid-masjid tersebar di seluruh dunia. Cordova yang menjadi salah satu sentra kejayaan Islam, pada tahun 1994 telah membangun Universitas Internasional "Averroess" yang tidak jauh dari masjid Cordova. Di 
sini kembali dikumandangkan adzan dan iqamah untuk shalat. Hal ini terjadi setelah 500 tahun umat Islam diusir terakhir dari Andalusia.

John L.Esposito mengatakan :'Masa depan Islam adalah tentang masa depan kita semua. Islam dan umat Islam masa kini adalah pemain integral dalam sejarah global . Mereka adalah bagian dari mozaik masyarakat Amerika dan Eropa. Dalam dunia di mana kita terlalu sering terjebak pada dikotomi antara 'kami' dan ''mereka' kita ditantang untuk mengatasi perbedaanperbedaan , menegaskan kemanusiaan kita dan menyadari bahwa kita -suka atau tidak suka-saling berhubungan (interconnect) dan co dependen serta co creation bersama masyarakat di dunia kita" (John L. Esposito: 2010:5).

\section{Kebangkitan Islam Peluang dan Tantangan}

Secara umum istilah kebangkitan Islam (Nahdhat al-Islam atau resurgent) memiliki tiga pengertian yaitu Pertama, pandangan dari dalam orang Islam itu sendiri bahwa kebangkitan Islam berarti bahwa Islam menjadi penting dalam berbagai aspek kehidupan dunia , kehidupan berbangsa, bermasyarakat dan kehidupan pribadi.

Kedua, kebangkitan Islam difahami sebagai mewujudkan suatu fenomena bahwa kemunculan sekarang Islam terkait dengan masa lalu. Kebesaran Islam masa lalu sebagai jalan hidup yang ditempuh nabi Muhammad Saw dan para sahabatnya mempunyai pengaruh kuat terhadap kehidupan saat ini.

Ketiga, kebangkitan Islam mengandung pengertian tantangan bahkan ancaman terhadap mereka yang memegang teguh pandangan hidup dan keyakinan lain (Chandra Muzaffar, 1993:23-26).

Sehubungan dengan kebangkitan tersebut kiranya perlu dipertanyakan kondisi Indonesia , Negara berpenduduk muslim terbesar di dunia : Apakah kebangkitan Islam memiliki peluang di Negara ini di masa depan. Kalau iya, bagaimana strategi yang perlu dilakukan untuk mewujudkannya.

Namun untuk menjelaskan posisi umat Islam dalam gagasan ini perlu kiranya dikemukakan ilustrasi mengenai kebangkitan Islam yang pernah dikemukakan oleh Said Ramadhan alButhi, menurutnya :

Sebagai umat terbaik (Khaira Ummah) sebenarnya setiap kemajuan dan keunggulan , apapun bentuknya oleh Tuhan diperuntukkan bagi hambahambaNya yang shalih. Kalau kemudian dalam kenyataannya kemajuan dan keunggulan itu melenceng ke tangan manusia yang tidak beriman, sebenarnya itu adalah Deviasi (penyimpangan).Bagaikan orang tua yang mempunyai dua orang anak yang satu baik dan yang satunya lagi nakal.Suatu ketika orang tua itu bermaksud hendak membeli mobil bagus bagi anaknya yang baik, Akan tetapi ketika mobil itu mau diambil di shawroom ternyata anak yang baik itu kebetulan berprilaku yang buruk yang menyebabkan mobil bagus tadi terpaksa diberikan pada anak yang nakal sebagai upaya untuk mendidik atau sebagai pelajaran bagi anak yang baik. Dapat diduga bahwa anak yang baik adalah orang beriman,sementara yang nakal adalah mereka yang durhaka pada Tuhan, yang menerima hadiah sementara karena anak yang baik sedang berbuat nakal (Said Ramadhan al-Buthi, 1985). 
Dalam kaitannya dengan kebangkitan Islam, terdapat sejumlah peluang yang dimanfaatkan oleh umat Islam untuk meraih kebangkitannya. Diantaranya :

1. Terjadinya kesadaran kolektif yang bersifat universal dari segenap umat Islam bahwa, kebangkitan Islam oleh Asghar Ali Engineer , misalnya, disebutkan telah menyentuh berbagai aspek fundamental dari kehidupan manusia yang dianalisisnya dalam konteks kebangkitan Islam politik, kebangkitan Islam ekonomi, kebangkitan Islam budaya dan kebangkitan Islam ritual (Ashgar Ali Engineer, 2000). Kesadaran kolektif tersebut menjadi potensi yang berkembang menjadi kekuatan yang dahsyat bagi dunia secara keseluruhan,apabila dapat didukung secara sistematis dan sungguh-sungguh oleh seluruh umat Islam bersama seluruh umat manusia.

2. Salah satu peluang bagi kebangkitan Islam adalah pluralisme yang menjadi ciri salah satu kehidupan global, sehingga umat Islam memiliki kesempatan yang seluas-luasnya untuk secara sistematis memperjuangkan kebangkitannya. Sebab kenyataannya semua masyarakat modern harus terbiasa dalam kehidupan lintas budaya, agama dan etnis.

3. Universalisme pendidikan dan ilmu pengetahuan yang semakin kukuh menyebabkan putra-putri Islam memiliki kesempatan menimba ilmu pengetahuan lintas universitas. Universalitas pendidikan yang memberikan kesempatan kepada putraputra muslimdiberbagai universitas terkemuka di dunia, ternyata telah mempercepat alih tehnologi dan perubahan sosial ke arah yang lebih maju. Hal ini tampaknya relevan dengan apa yang pernah ditulis oleh Bernard Lewis. " Setelah para diplomat , kelompok kedua (yang mengunjungi Eropa) dan yang lebih penting untuk kepentingan jangka panjang adalah orang-orang Timur Tengah yang menjadi mahasiswa di Eropa.Pada tahun 1820, 30, 40 dan seterusnya jumlah mereka di Universitas Eropa semakin banyak (Bernard Lewis, 1966).Bahkan seperti dikatakan oleh Bassam Tibbi,mahasiswa Islam yang belajar di Eropa telah menciptakan gelombang perubahan di dunia Islam, mereka bersifat aktif di masyarakat yang heterogen secara struktural baik dalam hal sosial budaya, ilmu pengetahuan dan ekonomi (Bassam Tibi, 1988).

4. Semakin banyaknya perguruan tinggi Islam dengan kesadaran modern yang tinggi dan metode pengembangan Sumber Daya Manusia ( SDM ) yang sistematis. Hal ini -sebagai salah satu penggerak perubahan akan menimbulkan perubahan yang Islami ditengah masyarakat.

5. Semangat keberagaman yang lebih intelektual, yang terbangun didorong oleh universitas-universitas yang kemudian menimbulkan gelombang kaum terdidik muslim yang sangat kreatifdi dunia Islam termasuk di Indonesia.

6. Membangun kesadaran yang lebih tinggi dikalangan kelas menengah untuk mengkaji dan mengembangkan kehidupan yang Islami di tengah kehidupan mereka.

7. Pembinaan agama melalui training- 
training, kursus-kursus dan paketpaket kajian Islami yang kini telah menimbulkan religiositas para pemimpin di setiap level.

Di samping sebagai peluang yang disebutkan, kebangkitan Islam ternyata berpapasan dengan berbagai tantangan, baik yang bersifat internal maupun eksternal. Para sarjana muslim telah mendiagnosis berbagai tantangan yang bersifat internal Islam, yang sekaligus merupakan faktor yang sering kali menyebabkan umat Islam sering tertinggal dari yang lain. Diantaranya yang terpenting adalah :

a. Tidak ada kepercayaan pada diri dan pemikiran sendiri. Banyak umat Islam yang telah mengabaikan rasionalitas dan peran akal dalam memahami dan mengimplementasikan Islam dalam kehidupan. Seperti yang pernah dikatakan oleh Muhammad Arkoun :"Kaum muslimin hampir mengabaikan langkah besar yang dilakukan akal untuk mengupayakan otonominya dan meningkatkan fungsinya. Dari sudut sejarah, pemikiran Islam telah mandek, tak mau lagi menerima perubahandalam prosedur-prosedurnya dan dalam kegiatan-kegiatannya. Sementara di Eropa, pemikiran sekuler terusmenerus bergerak maju sampai hari ini” (Muhammad Arkoun, 1987:38).

b. Tidak ada program yang jelas mengenai pembangunan masa depan umat akibat tidak tersedianya ilmu pengetahuan dan tehnologi yang yang memungkinkannya untuk menetapkan prinsip-prinsip budaya dalam upaya memerangi katerbelakangan.

c. Terjadi perpecahan dalam semua tingkat kehidupan.
Adapun dalam tantangan internal terjadi dengan daya tekan yang amat kuat. Tantangan itu ada yang terjadi dengan sendirinya sebagai keharusan sejarah perkembangan hubungan Islam dengan komunitas lain dan ada juga yang diopinikan dan/diopinikan. Di antaranya pertama, pencitraan yang negatif terhadap kebangkitan Islam. Asghar Ali Engineer misalnya menyebutkan bahwa media masa Barat (John L. Esposito, 1992) menjustifikasi kebangkitan Islam sebagai fanatisme keagamaan atau watak Islam sesungguhnya. Mereka menurut Asghar Ali telah memandang kebangkitan Islam secara keliru dan negatif.

Kekeliruan dalam pencitraan kebangkitan Islam itu juga disoroti oleh John L. Esposito yang disebutnya telah memandang bahwa kebangkitan Islam merupakan ancaman bagi komunitas yang lain termasuk masyarakat Barat. Kondisi itu dapat dimunculkan dengan sebutan Islam terorisme, fundamentalisme, radikalisme dan lain- lain. Dalam kenyataannya hal ini telah merugikan harmonitas dunia dan kemanusiaan. Kedua, Hipotesis beberapa ahli termasuk Samuel P. Huntington tentang The Clash Civilization, benturan peradaban yang memprediksi bahwa pasca perang dingin akan terjadi benturan antara dunia Barat dengan Timur, terutama dunia Islam. Hipotesis ini dikemudian hari seakan membuktikan atau ingin dibuktikan oleh kelompok yang menginginkan benturan itu benar-benar terjadi.

Ketiga, kenyataan bahwa supremasi media ditangan komunitas bukan muslim telah semakin meluluskan berbagai pencitraan negatif terhadap Islam dan berbagai upaya kebangkitannya diberbagai bagian dunia. Sementara komunitas 
muslim tidak dapat dengan leluasa melakukan klarifikasi atau informasi yang seimbang.

Keempat, materialisme dan pragmatism yang semakin berkembang telah menyebabkan suburnya ateisme, neo komunisme dan neo marxisme di berbagai penduduk dunia yang berpenduduk muslim, yang menyebabkan banyak orang termasuk umat Islam yang jatuh dari makhluk spiritual menjadi material.

\section{Strategi Mewujudkan Kebangkitan Islam}

Menurut pandangan umat Islam kebangkitan Islam pada hakikatnya adalah tugas kemanusiaan secara kolektif karena umat Islam merupakan bagian yang tak terpisahkan dari pembangunan dunia, dengan demikian merupakan tugas kemanusiaan. Sebagai suatu tugas kemanusiaan kolektif, maka setiap manusia membangkitan Islam diharapkan empat dukungan dan penghargaan yang layak dari seluruh umat manusia, lintas agama, geografi dan etnis.

Jika alam fikiran ini dapat diterima, maka upaya-upaya kebangkitan umat Islam seyogyanya tidak dapat dianggap sebagai ancaman, bahkan perlu disikapi sebagai kerja kolektif umat manusia yang secara teologis membawa mereka ke arah yang lebih baik dan sempurna.

Oleh karenanya berbagai upaya kebangkitan yang dilakukan umat Islam agar mengarahkan posisinya dari pinggiran ke pusat arus kebangkitan. Hal ini diperlukan karena dalam menyikapi fenomena itu ternyata umat Islam mengambil sikap dan tindakan yang variatif

, mulai dari yang sangat sederhana hingga yang sangat strategis, dari kebangkitan jalan santai hingga berlari mengejar ketertinggalan di segala bidang.

Salah satu kelemahan umat Islam termasuk para pemimpinnya-selama ini adalah karena tidak ada ketersediaan untuk mengevaluasi keabsahan tindakan dan kebijakan- kebijakan yang dilakukan untuk memajukan umat Islam.

Guna mewujudkan kebangkitan Islam tampaknya perlu dilakukan pengkajian ulang terhadap 'budaya kebangkitan' yang dimiliki umat Islam . Kemudian perlu melipatgandakan penguasaannya dimasa sekarang dan masa depan .

Yang dimaksud dengan budaya kebangkitan adalah tradisi dan prilaku yang dimiliki umat yang dimaksudkan untuk berpengaruh bagi kebangkitan umat Islam. Musthafa al-Shiba'I menginventarisasi sejumlah karakteristik budaya kebangkitan yang dimiliki umat Islam di zaman klasik yang disimpulkannya pada enam faktor yaitu 1). Keimanan yang kokoh, 2). Ilmu pengetahuan dan tehnologi.3). Kehidupan ekonomi yang handal. 4).Toleransi yang kuat. 5). Pelayanan sosial yang intensif dan efektif. 6).Pergaulan internasional yang kreatif dan mandiri.

Menganalogikan kebangkitan Islam Indonesia dengan klasik tersebut, maka upaya- upaya yang dilakukan oleh umat Islam Indonesia bisa bersifat kolektifinstitusional dan bersifat individual.

Upaya kolektif institusional adalah upaya sistematis yang dilakukan melalui berbagai lembaga dan organisasi Islam untuk meraih keunggulan dalam bidangnya.Di sini hendaknya mengetahui keberadaan organisasi Islam , Bank Islam, perusahaan Islam, lembaga pendidikan, universitas , pusat penelitian, pusat kajian, 
media masa, dan lembaga Islam lainnya untuk tercapainya kebangkitan Islam Indonesia.

Upaya-upaya individual dilakukan dengan menjadikan umat Islam sebagai orang yang memiliki budaya kebangkitan yang dapat membawa Islam kepada kebangkitan yang sesungguhnya. Partisipasi individual itu dapat dilakukan dalam meningkatkan kualitas diri dengan bonot manusia yang layak bangkit diantaranya :

Pertama, memiliki keimanan yang kokoh, kuat dan mandiri, bahwa Islam adalah jalan terbaik bagi kehidupan dan jalan kebangkitan.

Kedua, setiap muslim menampilkan Islam yang lebih murni dan ramah untuk mengeliminasi berbagai tindakan yang telah terkontaminasi dengan budaya asing yang tidak Islami. Dengan demikian, semua dilakukan dalam rangka kebangkitan itu memiliki kewibawaan etik. Seperti yang pernah disebutkan oleh Murrad Wilfred Hoffman :

"Aku tidak ingin melakukan operasi kecantikan pada wajah Islam dan menghilangkan kerut-kerutnya. Namun aku hanya ingin agar Islam lebih hidup, dinamis dan layak dengan menghilangkan karat-karat yang datang dari luar. Dengan ini ia akan kembali menemukan daya tarik aslinya".

Ketiga, memiliki komitmen yang kuat pada kebersamaan dan ukhuwah Islamiyah . Oleh karenanya pemuka agama dan pemimpin umat hendaknya menghindarkan diri dari 'etika ambiguitas', dalam penampilannya bersifat spiritual tapi pada kenyataannya bersifat kebendaan.

Keempat, memiliki pengetahuan dan skill serta etos kerja yang memadai agar
Mereka dapat mengelola rahmat dan nikmat Allah yang tiada bertepi diberbagai daerah untuk kemakmuran seluas-luasnya bagi seluruh anak manusia.

Kelima,memiliki optimisme bahwa perjalanan sejarah Islam adalah perjalanan yang teleologis, proses yang terus menerus menuju kebaikan dan kesempurnaannya.

1. Sebagaimana yang telah disebutkan bahwa salah satu kebangkitan Islam yaitu memiliki komitmen pada ukhuwah Islamiyah. Hal ini perlu ditegaskan bahwa paling tidak ada empat faktor penyebab umat Islam sering gagal mengaktualisasikan ukhuwah Islamiyah yaitu :

Kecenderungan mengartikan ukhuwah Islamiyah terbatas pada silaturahim fisik, saling mengunjungi, membantu yang terkena musibah,menjenguk yang sedang sakit,menghibur yang terkena musibah dan mendamaikan yang sedang sengketa. Pengertian di sini koridornya tidak diperluas menjadi universal dan holistic. Akibatnya menjadi banya wilayah-wilayah yang tak terfikirkan saat mengamalkan ukhuwah Islamiyah.

2. Ketidakmampuan sebagian besar umat Islam dalam melihat persoalan yang elementer dan teknis, sehingga persoalan yang elementer, teknis dan furu'iyah sering menyebabkan konflik horizontal antar-umat dan memisahkan sebagiannya dari arus perjalanan dan perjuangan global muslim. Menyadari hal itu diawal abad 20 Rasyid Ridha menuliskan pentingnya kesadaran umat Islam dalam kitabnya al-Wahdat al- Islamiyah.

3. Pragmatisme membuat sebagian umat tergoda dalam kepentingan sesaat 
untuk memenuhi keperluan pragmatis dan domestic sehingga seringkali merugikan, menyudutkan, dan menghianati kepentingan Islam yang lebih universal.

4. Politisasi agama, saat umat beragama dijadikan komoditas politik dan kesatuan mereka dicabik-cabik demi kepentingan sesaat. Hal ini terhubung dengan memudarnya sifat istiqamah dan idealisme religious sebagian tokoh agama.

Setelah menganalisis bagaimana pentingnya ukhuwah Islamiyah pada tataran kehidupan umat Islam, kiranya dapat dipelajari bagaimana petunjuk AlQur'an. Hal tersebut dapat dipelajari dari ayat berikut :

Sesungguhnya orang-orang mukmin bersaudara karena itu damaikanlah antara saudara-saudaramu dan bertakwalah pada Allah supaya kamu mendapat rahmat". QS. Al Hujurat : 10

Ayat di atas memberikan redaksi yang spesifik mengenai ukhuwah Islamiyah, ketika digunakan kata ikhwah. Sebab kitab suci ini menggunakan katakata tersebut disamping kata ikhwan untuk persaudaraan. Kata Ikhwah selalu digunakan untuk persaudaraan berdasarkan pertalian darah dan kata Ikhwan digunakan untuk persaudaraan berdasarkan pertalian-pertalian yang lain. Kecuali dalam ayat di atas untuk persaudaraan berdasarkan pertalian agama digunakan kata IKhwah, yang semestinya untuk persaudaraan berdasarkan pertalian hubungan darah.Makna ini menunjukkan betapa pentingnya persaudaraan/ ukhuwah Islamiyah itu, sehingga saudara seagama harus diperlakukan sebagai saudara kandung sendiri.

Pada sisi lain, ketika menyebut bahwa ukhuwah Islamiyah merupakan syarat mutlak untk terciptanya kompetisi sehat dalam menegakkan kebenaran, hal itu didasarkan pada firman

Allah surah al-“Asr : 3 : “ Kecuali orang-orang yang beriman dan beramal shalih dan saling menasehati untuk menaati kebenaran dan saling menasehati agar menepati kebenaran".

Mengingat pentingnya ukhuwah Rasulullah Saw memerintahkan untuk para sahabat sahabatnya terdiri dari kaum Anshar dan Muhajirin untuk saling berpegangan , sebagaimana yang diinformasikan oleh Ibnu Hisyam sebagai berikut :

"Rasulullah Saw mempersaudarakan para sahabatnya dari kaum Muhajirin dan Anshar seraya berkata :'Bersaudaralah kalian karena Allah, dua-dua". Kemudian serta merta beliau mengambil tangan Ali bin Abi Thalib seraya bersabda :" Ini adalah saudaraku" sehingga Rasulullah Saw bersama Ali menjadi ra menjadi dua saudara. Prilaku Rasulullah tersebut diikuti oleh para sahabat yang lain sehingga mereka berangkulan dua-dua seperti Hamzah bin Abi Thalib dengan Zaid bin Haritsah. Abu Bakar Shidiq dengan Kharijah bin Zuhair. Umar bin Khatab dengan 'Utbah bin Malik dan seterusnya (Ibnu Hisyam, 2006).

Dalam arti yang sempit ukhuwah Islamiyah dapat diartikan sebagai persaudaraan di antara sesama muslim. Namun dalam pengertian yang lebih luas dapat diartikan sebagai team kerja (Teamwork) orang beriman.

Terdapat sejumlah isyarat dalam AlQur'an bahwa ukhuwah Islamiyah itu berarti teamwork. Di antara firman Allah Swt dalam surat Al-Anfal ayat satu artinya: 
"Mereka bertanya padamu tentang harta rampasan perang. Katakanlah rampasan harta perang kepunyaan Allah dan rasulNya. Maka bertakwalah kamu kepada Allah dan perbaiki hubungan diantara kamu. Taatilah Allah dan rasulNya jika kamu orang yang beriman".

Abdullah Yusuf Ali menyebutkan pentingnya perbaikan jaringan orang beriman dalam perjuangan mereka di jalan Allah. Untuk itu mereka harus : 1). Bersatu dan menyisihkan perbedaanperbedaan kecil. 2). Niat tetap lurus. 3). Jangan dirusak oleh keserakahan harta dan kepentingan duniawi.

Berdasarkan pengertian tersebut maka kata faaslihu baina akhawaikum akan lebih komrehensif jika diartikan dengan perbaikilah hubungan /jaringan dunia modern celakalah masyarakat yang para pakar sosial, budaya dan etikanya buta huruf tentang ilmu pengetahuan dan teknologi dan para pakar ilmu pengetahuan dan tehnologi yang buta huruf yang mengenai masyarakat, budaya dan nilai".

Dengan team kerja yang solid, maka seorang muslim yang berkiprah dibidang agama akan dapat memahami apa yang dilakukan seorang muslim yang berkiprah di bidang tehnik, arsitektur dan sebagainya - Dan bila sikap saling memahami terlaksana dengan baik, maka pelaksanaan pembangunan akan terlaksana dengan koordinasi dengan baik sebagai tuntutan manajerial modern

Analisis di atas memperlihatkan bagaimana ukhuwah Islamiyah difahami dalam kontek kemoderenan dan dalam arti teamwork. Pemahaman dan aplikasi ukhuwah Islamiyah yang demikian dapat memberikan kontribusi penting bagi kemajuan dan kebangkitan umat Islam di setiap zaman.

\section{B. KESIMPULAN}

Umat Islam dalam sejarah mengalami kemajuan dan menguasai peradaban dunia. Hasil tersebut diraih karena mengikuti petunjuk yang berasal dari Allah Swt dan RasulNya Nabi Muhammad Saw. Sebaliknya akan mengalami kemunduran, kekalahan / kejumudan manakala bertentangan dengan ketentuan Sang Khaliq. Begitu juga sebaliknya kalau umat yang di luar Islam mengalami kemajuan karena meninggalkan ajarannya dan secara aplikasi sesuai dengan nilai-nilai Islam.

Kebangkitan Islam hendaknya menjadi peluang untuk mengembangkan kesadaran yang bersifat universal dan beragam sehingga memiliki kesempurnaan yang seluas-luasnya secara sistematis dan massif.

Secara periodesasi saat ini memasuki era moderen dan millennial yang semestinya umat Islam secara nyata bangkit meninggalkan ketertiggalannya dengan mengevaluasi secara Swot Analisis untuk menuju 'Izzu al Islam Wa al Muslimiin',Semoga.

\section{DAFTAR PUSTAKA}

Al-Imam Abi Muhammad 'abdul Malik bin Hisyam,al-Sirat al-Nabawiyah, (Beirut : Darul al-Kitab al-'Araby, 2006).

Ashgar Ali Engineer, Islam and Liberation Teology : Essay on Liberative Element In Islam, edisi Indonesia, Islam dan Teologi Pembebasan, (Yogyakarta : Pustaka Pelajar, 2000).

Bassam Tibi, The Crisis of Modern Islam : 
A Preindustrial in The Scientific Technological Age (Salt Lake City: University of Utah Press, 1988).

Bernard Lewis, The Middle East and The West (New York :1966).

Chandra Muzaffar, Kebangkitan Islam:

Suatu Pandangan Global dengan

Ilustrasi Asia Tenggara, Saiful

Muzani (ed), Pembangunan dan

Kebangkitan Islam di Asia

Tenggara, (Jakarta: LP3S, 1993).

Ibnu Hisyam, Al-Shirat al-Nabawiyah li Imam Ibnu Muhammad Abd Malik Ibn Hisyam, Amr Abd Salam alTadmiri , (Pentahqiq), jilid I dan II , (Beirut : Darul Kitab Al-'Arabi, 2006).

John L. Esposito, The Islamic Threat: Myth or Reality, ( New York: Oxford University Press), 1992 Muhammad Arkoun, Menuju Pendekatan Baru Islam, dalam 'Ulumul Qur'an, No. 7 (1987).

Muhammad Rasyid Ridha, al-Wahdah alIslamiyah wa al-Ukhuwah alDiniyahwa Tauhidal-Madzahib, (Beirut: Dar al-Maktabah alIslamiyah,tt)
Musthafa Al-Siba'I, Min Rawa'I Hadharatana

M.M. Syarif, History of Muslim Philosophy, (Delhi-India: Adam Publisher \& Distributor, 2001).

Said Nursi, Badi'uzaman, Khutbah Syamiyah Manifesto Kebangkitan Umat Islam, Risalah Nur Press, Jakarta, 2014,

Said Ramadhan al-Buthi, Man al-Mas'ul an Takhalluf al-Muslimin, (Damaskus: Muassasah al-Risalah , 1985).

Samuel P. Huntington, The Clash of Civilization, Foreign Affairs, (Musim Panas,1993

Shahih Muslim dalam bab Fadhail alShahabah, 210, 211, 213, 214, 215: Abu Daud, 9, Ahmad bin Hambal 2, 328

Sunan Abu Daud, Mulahim 1

Soejatmoko, Manusia dan Dunia yang sedang Berubah, dalam Conny R, Semiawan.

Syed Amir Ali, The Spirit Of Islam : A History of The Evolution and Ideal of Islam, (London: W.I). 